Agustus 2018

\title{
PENGARUH UKURAN MATA JARING (MESH SIZE) ALAT TANGKAP JARING INSANG (GILL NET) TERHADAP HASIL TANGKAPAN DI SUNGAI LIRIK KECAMATAN JANGKAT TIMUR KABUPATEN MERANGIN PROVINSI JAMBI
}

\author{
Al Irpan*, Djunaidi** dan Rini Hertati** \\ * Alumnus Program Studi Pemanfaatan Sumberdaya Perikanan Fakultas Perikanan \\ Dosen Program Studi Pemanfaatan Sumberdaya Perikanan Fakultas Perikanan
}

\begin{abstract}
ABSTRAK
Penelitian ini dilaksanakan selama 5 bulan yaitu dari tanggal 07 November 2017 sampai tanggal 06 Maret 2018 di Sungai Lirik Kecamatan Jangkat Timur Kabupaten Merangin Provinsi Jambi. Tujuan penelitian ini adalah untuk mengetahui ukuran mata jaring (mesh size) yang terbaik untuk mengetahui hasil tangkapan dan jenis ikan yang tertangkap dengan ukuran mata jaring (mesh size) jaring insang yang berbeda di Sungai Lirik Kecamatan Jangkat Timur.

Alat tangkap jaring insang (gill net) yang dioperasikan dalam penelitian ini sebanyak 3 unit dengan ukuran mata jaring yang berbeda yaitu mes size 1 inchi 1,5 inchi dan 2,5 inchi. Metode yang digunakan dalam penelitian ini adalah metode observasi lansung ke lapangan dan metode penentuan stasiun sampel dilakukan dengan cara Purpossive dengan menggunakan Rancak Acak Lengkap (RAL) dengan 3 perlakuan dan 5 ulangan dan uji Anova. Parameter yang diamati adalah pengaruh perbedaan ukuran mata jaring (mesh size) terhadap ukuran total ukuran (berat, panjang dan Tinggi) hasil tangkapan, jumlah total (ekor) hasil tangkapan serta jenis ikan yang tertangkap di Sungai Lirik.

Hasil penelitian menunjukan bahwa perbedaan mata jaring insang (gillnet) 1 inchi, 1,5 inchi dan 2 inchi berpengaruh nyata terhadap ukuran ikan (berat $(\mathrm{Kg})$, panjang $(\mathrm{cm})$ dan tinggi $(\mathrm{cm})$ ikan), jumlah total (ekor) ikan yang tertangkap (F Hit $>$ F Tabel). Jenis ikan yang tertangkap pengaruh perbedaan mata jaring insang (gillnet) di sungai Lirik di jumpai 3 jenis ikan yaitu semah (Labeobarbus tambra) sebanyak 128 ekor, ikan Kepyur (Barbodes lateristriga) 7 ekor dan ikan Baung (Hemibagrus nemurus) sebanyak 1 ekor serta ukuran mata jaring (mesh size) alat tangkap jaring insang (gill net) yang terbaik digunakan adalah : 2 Inchi Berdasarkan ukuran ikan (Berat, panjang dan tinggi) dan mata jaring (mesh size) 1 Inchi untuk hasil tangkapan.
\end{abstract}

\section{Kata Kunci : Mesh Size, Mata Jaring}

\section{PENDAHULUAN}

Sungai merupakan suatu bentuk ekosistem lotik (perairan mengalir) yang berfungsi sebagai tempat hidup bagi organisme makro ataupun mikro, baik yang menetap ataupun berpindah-pindah. Organisme yang hidup dalam sungai merupakan organisme yang memiliki kemampuan beradaptasi terhadap kecepatan arus atau aliran air (Febriansyah, 2011).

Berdasarkan survei yang telah dilakukan, sungai Lirik merupakan salah satu Sungai di Kabupaten Merangin tepatnya di Kecamatan Jangkat Timur. Sungai Lirik dengan panjang sungai $\pm 15 \mathrm{Km}$ dan lebar \pm 8 $\mathrm{m}$ dan kedalaman lebih kurang $\pm 5 \mathrm{~m}$. Di bagian hulu memiliki tipe ekologi perairan berarus deras sampai sedang dan umumnya berbatu. Di sekeliling sungai merupakan daerah persawahan dan perkebunan. Di Sungai Lirik ini, nelayan banyak melakukan penangkapan ikan-ikan konsumsi untuk memenuhi kebutuhan masyarakat (domestik). Jenis-jenis ikan yang bernilai ekonomi tinggi seperti ikan semah telah banyak diperdagangkan.

Sungai Lirik saat ini dimanfaatkan oleh masyarakat nelayan untuk usaha penangkapan ikan dengan jumlah nelayan sebanyak 140 orang dengan rincian 93 orang nelayan jaring 
insang, 16 orang nelayan jala tebar dan 31 orang nelayan bubu (Sumber : Nelayan setempat). Berbagai aktivitas penangkapan ikan telah dilakukan oleh para nelayan yang mendiami kawasan sungai ini, seperti usaha penangkapan ikan, alat tangkap yang digunakan umumnya dirancang sendiri berdasarkan pengalaman (Najamuddin, 2011), hambatan yang ditemui saat operasi penangkapan, tanpa adanya perhitungan dan pertimbangan yang mendetail. Salah satu alat yang digunakan untuk penangkapan ikan di sungai ini adalah jaring insang atau Gill net (jaring insang). Hal ini sesuai dengan pendapat Dinas Peternakan dan Perikanan Merangin (2015), alat tangkap jaring insang atau gill net paling banyak digunakan di Kecamatan Jangkat. Usaha penangkapan ikan dengan menggunakan jaring insang atau Gill net sudah bukan merupakan teknologi yang baru bagi para nelayan, hal ini disebabkan karena bahannya lebih mudah diperoleh, secara teknis mudah dioperasikan, secara ekonomis bisa dijangkau oleh nelayan, dan lebih selektif terhadap ukuran ikan yang tertangkap (Tawari, 2013)

Jaring insang atau Gill net adalah satu jenis alat tangkap ikan dari bahan jaring yang bentuknya empat persegi panjang dengan ukuran mata jaring yang sama besar, jumlah mata jaring ke arah horizontal jauh lebih banyak dari pada jumlah mata jaring ke arah vertikal, pada bagian atas dilengkapi beberapa pelampung dan di bagian bawah dilengkapi beberapa pemberat sehingga memungkinkan jaring dapat dipasang di daerah penangkapan dalam keadaan tegak (Martasuganda, 2002).

Menurut Dincer dan Bahar (2008) mata jaring pada jaring insang atau gill net merupakan faktor yang sangat berpengaruh terhadap ukuran hasil tangkapan. Lebih lanjut Hamley (1975) dalam Iskandar dkk (2015) berpendapat bahwa mesh size gillnet tidak hanya berpengaruh terhadap ukuran hasil tangkapan namun juga jumlah hasil tangkapan. Hasil penelitian Efton (2015) menunjukan bahwa perbedaan mata jaring insang tetap (gillnet) 1,33 inchi, 2,15 inchi dan 2,59 inchi berpengaruh sangat nyata terhadap ukuran total berat (gram), panjang $(\mathrm{cm})$ dan lebar $(\mathrm{cm})$ ikan dan jumlah ikan (ekor) ikan yang tertangkap di sungai Menyabu Kabupaten Merangin Propinsi Jambi. Dan ukuran mata jaring yang tebaik digunakan adalah : ukuran 2,59 inchi berdasarkan ukuran total Berat, panjang dan lebar sedangkan berdasarkan jumlah ikan (ekor) adalah diperoleh ukuran ukuran 3,4 cm (1,33 inchi) serta terdapat 3 jenis ikan dan 1 ekor udang yang tertangkap selama melakukan penelitian.

penelitian ini bertujuan untuk mengetahui bagaimana hasil tangkapan ikan dan jenis ikan yang tertangkap dengan ukuran mata jaring insang yang berbeda serta ukuran mata jaring insang manakah yang paling baik digunakan untuk menangkap ikan di Sungai Lirik Kecamatan Jangkat Timur.

Berdasarkan uraian diatas maka penulis tertarik untuk melakukan penelitian dengan judul "Pengaruh Ukuran Mata Jaring (Mesh Size) Alat Tangkap Jaring insang (Gill net) Terhadap Hasil Tangkapan di Sungai Lirik Kecamatan Jangkat Timur Kabupaten Merangin Provinsi Jambi.

\section{METODE PENELITIAN}

Penelitian ini dilakukan di Sungai Lirik Kecamatan Jangkat Timur Kabupaten Merangin dan penelitian ini dilaksanakan dari bulan November 2017 sampai bulan Maret 2018. Peta lokasi penelitian dapat dilihat pada Gambar 3.3.

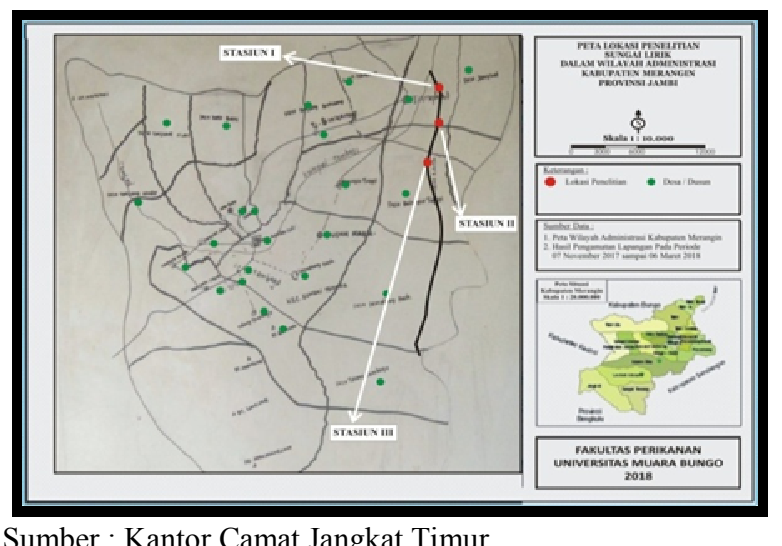

Gambar 1. Peta Lokasi Penelitian

Peralatan yang digunakan untuk penelitian ini yaitu : alat tangkap jaring insang sebanyak 3 unit dengan ukuran mesh size yang berbeda yaitu mesh size $2,5 \mathrm{~cm}$ (1 inchi), 3,8 $\mathrm{cm} \quad(1,5$ inchi $)$ dan $5 \mathrm{~cm} \quad(2$ inchi $)$. 
Mistar/meteran, kamera digital, alat tulis, timbangan dan Hand Phone.

Untuk pengumpulan data digunakan data primer dengan cara observasi langsung kelapangan dan data sekunder diambil dari instansi yang terkait seperti dinas perikanan, Badan Pusat Statistik serta literatur-literatur yang berhubungan dengan penelitian ini. Metode penentuan stasiun pengambilan sampel dilakukan dengan cara purposive sampling dimana penentuan stasiun sesuai dengan tujuan penelitian. Adapun deskripsi masing-masing Stasiun adalah sebagai berikut :

1. Stasiun I berada pada daerah lubuk Cempedak ditandai dengan bambu dan semak belukar disekitar lubuk $\pm 2 \mathrm{Km}$ dari Stasiun II dan berjarak $\pm 5 \mathrm{Km}$ dari Stasiun III dengan titik koordinat $2^{0} 32^{\prime} 7^{\prime \prime}$ LS dan $102^{0} 3^{\prime} 51^{\prime \prime}$ BT.

2. Stasiun II berada di sekitar wilayah lubuk kembang yang ditandai oleh pohon-pohon dengan jarak $\pm 2 \mathrm{~km}$ dari Stasiun I dan Stasiun III $\pm 3 \mathrm{Km}$ dan titik koordinat $2^{0}$ 31' 54" LS dan $102^{0} 3^{\prime} 53^{\prime \prime}$ BT.

3. Stasiun III berada di wilayah lubuk dan sekitar pertanian dan perkebunan masyarakat dengan titik koordinat $2^{0} 31^{\prime}$ 37" LS dan $102^{\circ} 3^{\prime} 52^{\prime \prime}$ BT.

Jaring yang digunakan mempunyai ukuran, panjang 7 meter, lebar 1 meter dengan ukuran mata jaring yang berbeda yaitu $2,5 \mathrm{~cm}$ (1 inchi), $3,8 \mathrm{~cm}$ (1,5 inchi) dan $5 \mathrm{~cm}$ (2 inchi). Pada bagian atas jaring (tali ris atas) terdapat pelampung sebanyak 1 buah tiap meternya, sedangkan pada bagian bawahnya (tali ris bawah) dikaitkan dengan pemberat sebanyak 4 buah tiap meternya. Pelampung dan pemberat berguna untuk menegakkan posisi jaring selama di dalam air agar tidak terbawa arus atau gelombang.

Jaring insang akan dipasang horizontal melintang Sungai dengan sistem pemasangan secara zig-zag dan dipasang secara serentak pada lokasi yang telah ditentukan pada Jam $16{ }^{00}$ WIB (sore hari) dan diangkat pada keesokan hari yaitu jam $8^{00}$ WIB (paginya). Ikan yang diperoleh kemudian dipisahkan berdasarkan ukuran mata jaring dimana ikan tersebut tertangkap. Contoh ikan kemudian diukur panjangnya menggunakan papan ukur dengan ketelitian $0,1 \mathrm{~cm}$ dan ditimbang beratnya dengan menggunakan timbangan ketelitian $0,1 \mathrm{~g}$.

Data yang dikumpulkan meliputi jenis ikan, panjang dan berat ikan, jumlah jenis, lokasi, waktu pemasangan alat tangkap dan pengangkatannya, kedalaman perairan, dan ukuran mata jaring. Data jenis ikan yang tertangkap dengan menggunakan jaring selanjutnya ditentifikasikan menggunakan bahan timbangan, mistar dan kemudian ditabulasi untuk dianalisa. Untuk lebih jelasnya mengenai data yang dikumpulkan dapat dilihat pada Tabel 1.

Tabel 1. Tabel Hasil Pengamatan

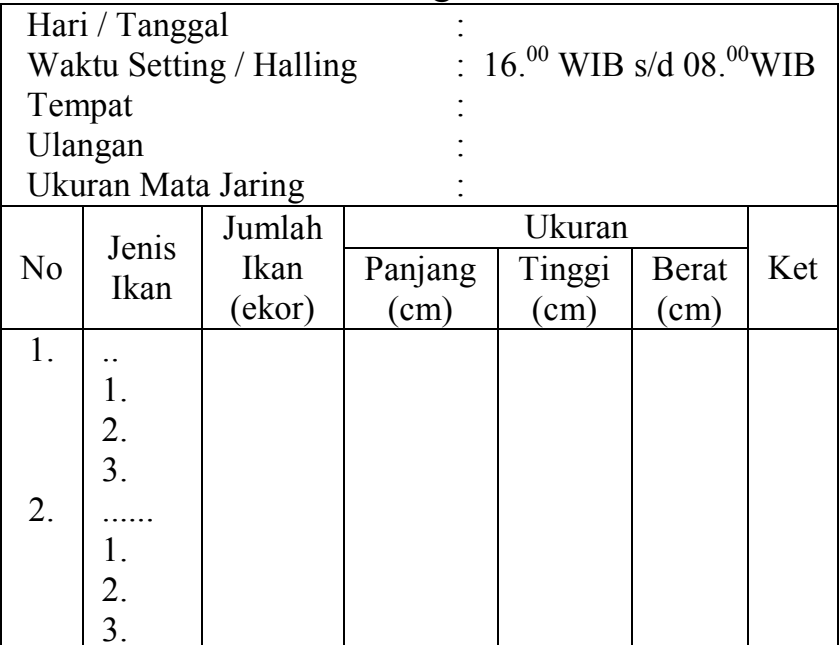

Sumber : Rancangan Penelitian

Rancangan yang di gunakan dalam penelitian ini adalah Rancangan Acak Lengkap (RAL) dengan 5 ulangan dan 3 perlakuan mata jaring insang tetap yang berbeda yaitu mata jaring size $2,5 \mathrm{~cm}$ (1 inchi), 3,8 cm (1,5 inchi) dan $5 \mathrm{~cm}$ (2 inchi). Asumsi dasar untuk percobaan dengan rancangan acak lengkap adalah hasil pengamatan $\mathrm{Xij}$ dapat dituliskan dengan model aditif sebagai berikut :

$\mathrm{Yij}=\mu+\tau \mathrm{i}+\epsilon \mathrm{ij}$

$\mathrm{i}=1,2,3,4 \ldots \ldots . . \mathrm{t}$

$\mathrm{j}=1,2,3,4,5 \ldots . . \mathrm{r}$

Keterangan :

Yij = Nilai tengah pengamatan pada satuan percobaan ke-j yang terdapat perlakuan ke-i

$\mu \quad=$ Nilai tengah umum

$\tau \mathrm{i}=$ Pengaruh perlakuan ke $\mathrm{i}$

$\epsilon i j=$ Pengaruh sisa pada satuan percobaan ke-j yang mendapat perlakuan $\mathrm{ke}-\mathrm{i}$

$\mathrm{t}=$ Jumlah perlakuan 
$\mathrm{r} \quad=$ Jumlah ulangan pada perlakuan ke-i Dengan asumsi :

1. Ikan tertangkap mempunyai kesempatan yang sama

2. habitat hidup ikan dianggap sama

3. Ikan tersebar merata

Data yang didapat dianalisis guna mengetahui keragaman data yang diperoleh dilakukan analisis Sidik Ragam (RAL) dengan tingkat kepercayaan 95\%. Apabila $\mathrm{F}$ hitung $<\mathrm{F}$ tabel maka $\mathrm{H} 0$ diterima dan $\mathrm{H} 1$ ditolak yang berarti tidak ada pengaruh ukuran mata jaring terhadap hasil tangkapan ikan dan apabila $\mathrm{F}$ hitung $>\mathrm{F}$ tabel maka $\mathrm{H} 0$ ditolak dan $\mathrm{H} 1$ diterima sehingga ada pengaruh ukuran mata jaring terhadap hasil tangkapan ikan (Ledhyane I.H, 2013). Selanjutnya Ikan yang tertangkap diukur tinggi, panjang dan berat total berdasarkan ukuran mata jaring. Kisaran tinggi, panjang dan berat total ikan pada masingmasing mata jaring dibandingkan satu dengan lainnya untuk mengetahui perbandingan variasi ukuran ikan yang tertangkap. Untuk mengetahui hasil tangkapan ikan per alat tangkap maka ikan hasil tangkapan dipisahkan, dicatat dan ditabulasikan berdasarkan ukuran mata jaring/lokasi. Total hasil tangkapan dihitung dari penjumlahan data hasil tangkapan/alat tangkap/lokasi.

\section{HASIL DAN PEMBAHASAN}

\section{A. Pengaruh Ukuran Mata Jaring (mesh size) Terhadap Ukuran Ikan yang Tertangkap di Sungai Lirik Kecamatan Jangkat Timur}

\section{Berat Ikan (gram)}

Berdasarkan hasil penelitian terhadap berat ikan yang tertangkap pada masing-masing stasiun dari setiap ukuran mata jaring (mesh size) dapat dilihat pada lampiran 2. Perbandingan berat ikan yang tertangkap pada masing-masing stasiun penelitian dapat dilihat pada Tabel 2.

Tabel 2. Berat (gram) Hasil Tangkapan Jaring Insang (Gill Net) Dengan Ukuran Mata Jaring (Mesh Size) Berbeda Di Sungai Lirik

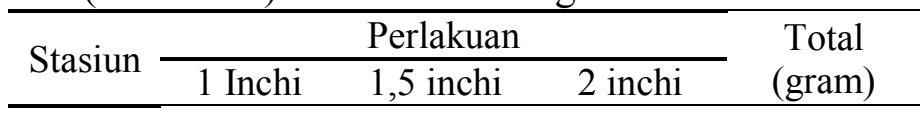

\begin{tabular}{|c|c|c|c|c|}
\hline & (gram) & (gram) & (gram) & \\
\hline I & 625,00 & $1.140,00$ & $1.095,00$ & 2860,00 \\
\hline II & 529,00 & 1015,00 & 920,00 & 2464,00 \\
\hline III & 665,00 & 730,00 & 1014,00 & 2409,00 \\
\hline Total & 1819,00 & 2885,00 & 3029,00 & 7733,00 \\
\hline Rata $^{2}$ & 606,33 & 961,67 & $1.009,67$ & $2.577,67$ \\
\hline
\end{tabular}

Sumber : Hasil Penelitian, 07 November $2017-06$ Maret 2018

Berdasarkan Tabel 2 di atas dapat dilihat bahwa berat total $(\mathrm{Kg})$ ikan yang tertangkap selama penelitian adalah sebanyak 7.733 gram. Perlakuan dengan ukuran mata jaring insang (gill net) 2 inchi merupakan ukuran berat total ikan yang terberat yaitu dengan rata-rata $1.009,67$ gram, hal ini dikarenakan ukuran mata jaring (mesh size) yang besar sehingga ikan yang tertangkap juga berukuran besar. Sedangkan berat ikan yang paling ringan terdapat pada perlakuan dengan ukuran mata jaring (mesh size) 1 Inchi yaitu sebanyak 1.819,00 dengan rata-rata 606,33 gram. Sehingga dapat disimpulkan bahwa berbedanya ukuran mata jaring (mesh size) alat tangkap jaring insang (gill net) berbeda pula ukuran berat ikan yang tertangkap. Manalu (2003) menyatakan bahwa semakin besar ukuran mata jaring, maka akan semakin besar pula ikan yang tertangkap. Lebih lanjut Sudirman dan Mallawa (2004) menjelaskan bahwa antara mesh size dari gillnet dan besar ikan yang terjerat terdapat hubungan yang erat. Secara rinci hsitogram ukuran berat total ikan hasil tangkapan jaring insang (gill net) pada setiap mesh size disajikan pada Gambar 2.

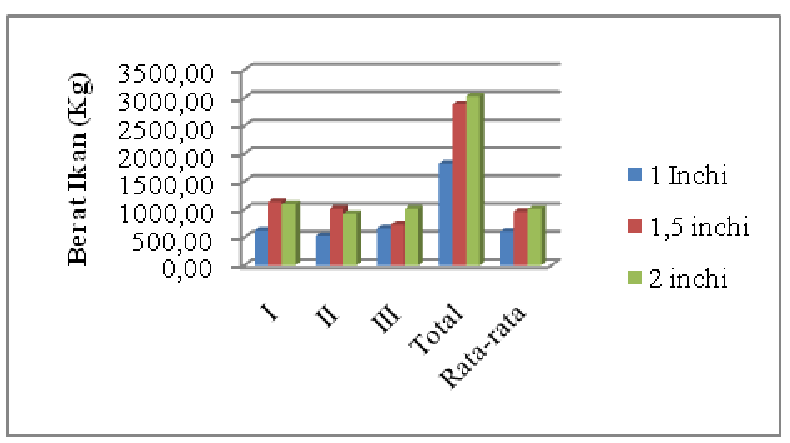

Gambar 2. Histogram Berat (Kg) Ikan hasil tangkapan jaring insang dengan ukuran mata jaring (mesh size) yang berbeda.

Berdasarkan histogram pada Gambar 2 diatas dapat dijelaskan bahwa berat ikan yang tertangkap pada ukuran mata jaring (mesh size) 
2 inchi merupakan ikan yang terberat pada setiap stasiun (stasiun I, II dan III) dan diikuti ukuran mata jaring (mesh size) 1,5 inchi dan ukuran mata jaring (mesh size) 1 inchi menupakan berat ikat yang paling ringan, hal ini juga terlihat dari total dan rata-rata berat ikan yang tertangkap pada setiap perlakuan ukuran mata jaring (mesh size) alat tangkap jaring insang yang berbeda.

Untuk melihat adanya pengaruh ukuran mata jaring (mesh size) yang berbeda terhadap berat ikan yang tertangkap dilakukan analisis ragam (anova) yang menunjukan bahwa $\mathrm{F}$ tabel $>$ Ftabel maka H0 ditolak dan terima $\mathrm{H} 1$ yang artinya perlakuan ukuran mata jaring (mesh size) alat tangkap jaring insang (gill net) yang berbeda berpengaruh nyata terhadap ukuran berat (gram) ikan yang tertangkap hal ini disebabkan karena ukuran mesh size jaring insang yang besar hanya menangkap ikan dengan ukuran yang besar, ikan dengan ukuran besar tentu mempunyai ukuran berat yang besar dan ukuran mesh size jaring insang yang kecil tentu juga akan akan menangkap ikan dengan berat yang lebih kecil. Heikinheimo, et al.(2006) menyatakan bahwa perubahan penggunaan ukuran mata jaring dari $43,45 \mathrm{~mm}$ ke ukuran $50 \mathrm{~mm}$ juga menyebabkan perbedaan terhadap total berat kasar hasil tangkapan. Kheng (2008) juga menyatakan, bahwa ukuran mata jaring berbeda akan memperoleh ukuran ikan yang berbeda-beda. Lebih lanjut Dincer dan Bahar (2008) menyatakan bahwa mata jaring pada gillnet merupakan faktor yang sangat berpengaruh terhadap ukuran hasil tangkapan.

\section{Panjang Ikan (cm)}

Berdasarkan hasil penelitian terhadap ukuran panjang ikan yang tertangkap pada masing-masing stasiun dari setiap ukuran mata jaring (mesh size) dapat dilihat pada lampiran 4. Perbandingan ukuran panjang ikan yang tertangkap pada masing-masing stasiun penelitian dapat dilihat pada Tabel 3.

Tabel 3. Ukuran Panjang $(\mathrm{cm})$ Hasil Tangkapan Jaring Insang (Gill Net) Dengan Ukuran Mata Jaring (Mesh Size) Berbeda Di Sungai Lirik

\begin{tabular}{|c|c|c|c|c|}
\hline \multirow{2}{*}{ Stasiun } & \multicolumn{3}{|c|}{ Perlakuan } & \multirow{2}{*}{$\begin{array}{l}\text { Total } \\
(\mathrm{cm})\end{array}$} \\
\hline & 1 & 1,5 & 2 & \\
\hline
\end{tabular}

\begin{tabular}{ccccc}
\hline & inchi & inchi & inchi & \\
& $(\mathrm{cm})$ & $(\mathrm{cm})$ & $(\mathrm{cm})$ & \\
\hline I & 12,29 & 18,00 & 22,78 & 53,07 \\
II & 13,76 & 17,54 & 22,66 & 53,96 \\
III & 13,79 & 18,07 & 22,79 & 54,65 \\
\hline Total & 39,83 & 53,61 & 68,24 & 161,68 \\
\hline Rata-rata & 13,28 & 17,87 & 22,75 & 53,89 \\
\hline
\end{tabular}

Sumber : Hasil Penelitian, 07 November 2017 - 06 Maret 2018

Dari Tabel 3. dapat disimpulkan bahwa rata-rata total ukuran panjang ikan yang tertangkap selama penelitian adalah sepanjang 53,89 $\mathrm{cm}$ dan Perlakuan dengan ukuran mata jaring (mesh size) alat tangkap jaring insang (gill net) 2 inchi merupakan ukuran panjang rata-rata panjang ikan yang terpanjang yaitu $22,75 \mathrm{~cm}$ dan rata-rata ukuran panjang ikan yang terpendek yaitu pada perlakuan 1 inchi yaitu sebesar 13,28 cm hal ini karena ikan yang tertangkap sesuai dengan luas bukaan ukuran mata jaring (mesh size) insang, pada perlakuan 2 inchi mempunyai luas bukaan mata jaring yang besar sehingga ikan yang tertangkap juga panjang begitu juga pada perlakuan 1 inchi mempunyai luas bukaan mata jaring yang lebih kecil sehingga ikan yang tertangkap juga berukuran kecil. Hal ini sesuai dengan pernyataan Hamley (1975) dalam Delly (2011) yang menyatakan bahwa lingkar tubuh maksimum dapat menggambarkan secara tepat bagaimana ukuran ikan itu sendiri mempengaruhi selektivitas jaring. Karenanya seleksi ukuran mata jaring menjadi penting dalam penentuan konstruksi jaring insang, dimana perlu mempertimbangkan ukuran tubuh ikan yang menjadi tujuan penangkapan. Menurut Næsje, et al (2004) dalam Prianto dan Wijaya (2012) bahwa gill net merupakan alat tangkap yang selektif, dalam pengoperasiannya ukuran mata jaring yang berbeda akan menangkap jenis dan ukuran ikan yang berbeda.

Untuk melihat hsitogram panjang ikan hasil tangkapan jaring insang (gill net) pada setiap ukuran mata jaring (mesh size) yang diteliti disajikan pada Gambar 3 di bawah . 
SEMAH : Journal Pengelolaan Sumberdaya Perairan VOL. 2 No. 2

Agustus 2018

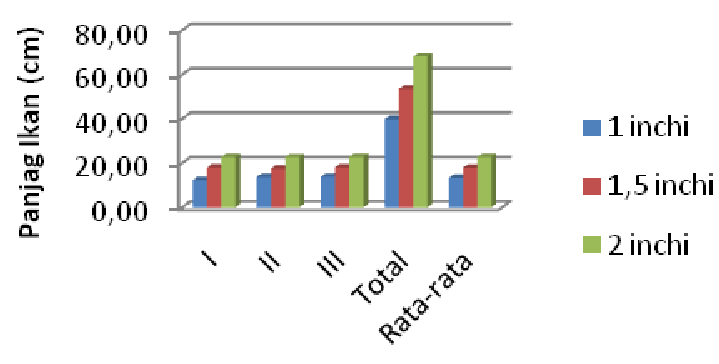

Gambar 3 Histogram Ukuran Panjang $(\mathrm{cm})$ hasil tangkapan jaring insang pengaruh ukuran mata jaring (mesh size) yang berbeda.

Dari gambar 3 di atas dapat dijelaskan bahwa ukuran panjang ikan yang paling panjang tertangkap jaring insang pada setiap stasiun (satsiun I, II dan III) adalah pada perlakuan 2 inchi dan diikuti perlakuan 1,5 inchi dan perlakuan 1 inchi yang merupakan ukuran mata jaring (mesh size) terkecil dengan ukuran panjang ikan juga terkecil hal ini juga dapat di lihat pada pada total dan rata-rata panjang ikan yang berbeda karena berbedanya ukuran mata jaring insang (mesh size).

Untuk melihat adanya pengaruh ukuran mata jaring (mesh size) terhadap ukuran panjang ikan yang tertangkap dilakukan analisis ragam (anova) yang Dari Tabel 5 dapat disimpulkan bahwa perbedaan ukuran mata jaring (mesh size) berpengaruh sangat nyata terhadap panjang ikan yang tertangkap di sungai lirik yang dapat dilihat dari hasil sidik ragam pada tingkat $95 \%$ dimana nilai Fhitung $>$ dari Ftabel sehingga H1 diterima dan H0 ditolak. yang artinya perlakuan ukuran mata jaring (mesh size) yang berbeda berpengaruh nyata terhadap ukuran panjang $(\mathrm{cm})$ ikan yang tertangkap hal ini dikarenakan rata-rata panjang ikan yang tertangkap dengan ukuran mata jaring (mesh size) yang lebih besar (2 inchi) juga lebih panjang dibandingkan dengan ukuran 1,5 inchi dan 1 inchi. Kenyataan sesuai yang dikemukan oleh Krisnamorthi dalam Firmansyah (1988) yang menyatakan bahwa ukuran ikan yang tertangkat akan lebih besar pada gill net yang mempunyai ukuran mata lebih besar. Lebih lanjut Ayodhyoa (1981) menyatakan bahwa terdapat hubungan yang erat antara ukuran mata jaring dengan ukuran ikan yang tertangkap

\section{Tinggi Ikan (cm)}

ojs.umb-bungo.ac.id/index-php/SEMAHJPSP

ISSN : 2580-0736

Berdasarkan hasil penelitian terhadap ukuran Tinggi ikan yang tertangkap pada masing-masing stasiun dari setiap ukuran mata jaring (mesh size) dapat dilihat pada lampiran 6. Perbandingan ukuran tinggi ikan yang tertangkap pada masing-masing stasiun penelitian dapat dilihat pada Tabel 4.

Tabel 4. Ukuran Tinggi (cm) Hasil Tangkapan Jaring Insang (Gill Net) Dengan Ukuran Mata Jaring (Mesh Size) Berbeda Di Sungai Lirik

\begin{tabular}{|c|c|c|c|c|}
\hline \multirow[b]{2}{*}{ Stasiun } & \multicolumn{3}{|c|}{ Perlakuan } & \multirow{2}{*}{$\begin{array}{l}\text { Total } \\
(\mathrm{cm})\end{array}$} \\
\hline & $\begin{array}{l}1 \text { inchi } \\
(\mathrm{cm})\end{array}$ & $\begin{array}{l}1,5 \text { inchi } \\
(\mathrm{cm})\end{array}$ & $\begin{array}{l}2 \text { inchi } \\
(\mathrm{cm})\end{array}$ & \\
\hline I & 2,99 & 4,03 & 5,29 & 12,31 \\
\hline II & 2,95 & 4,08 & 5,27 & 12,30 \\
\hline III & 2,84 & 4,11 & 5,31 & 12,27 \\
\hline Total & 8,79 & 12,22 & 15,88 & 36,88 \\
\hline Rata-rata & 2,93 & 4,07 & 5,29 & 12,29 \\
\hline
\end{tabular}

sumber : Hasil Penelitian, 07 November 2017 - 06 Maret 2018

Pada Tabel 4 terlihat bahwa rata-rata tinggi total ikan yang tertangkap selama penelitian adalah 12,29 $\mathrm{cm}$. Berbedanya ukuran mata jaring (mesh size) alat tangkap jaring insang maka berbeda pula ukuran tinggi ikan yang tertangkap sesuai dengan ukuran mata jaring (mesh size) yang digunakan. Rata-rata ukuran tinggi ikan pada perlakuan ukuran mata jaring (mesh size) 2 inchi merupakan ukuran tinggi yang terbesar yaitu $5,29 \mathrm{~cm}$ dan diikuti oleh ukuran mata jaring (mesh size) 1,5 inchi sebesar 4,07 cm dan ukuran mata jaring (mesh size) 1 inchi sebesar 2,93 yang merupakan ukuran tinggi terkecil. Rounsefell dan Everhart (1960) dalam Pratiwi (2010) menyatakan bahwa ukuran dan jenis ikan yang tertangkap oleh gillnet bervariasi tergantung pada ukuran mata jaring yang digunakan dan dengan ukuran mata jaring tertentu ada kecenderungan hanya menangkap ikan yang mempunyai fork length, girth dan berat pada selang tertentu pula. Selanjutnya King (1995) menyatakan bahwa ukuran mata jaring didesain untuk menagkap spesies dan ukuran ikan tertentu.

Untuk melihat hsitogram tinggi ikan hasil tangkapan jaring insang (gill net) pada setiap ukuran mata jaring (mesh size) yang diteliti disajikan pada Gambar 4 berikut : 


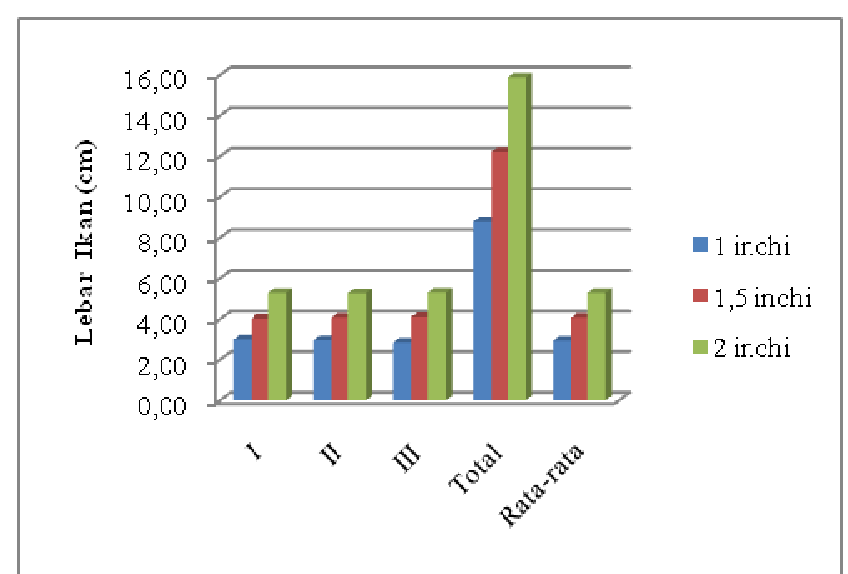

Gambar 4. Histogram Ukuran Tinggi (cm) hasil tangkapan jaring insang pengaruh ukuran mata jaring (mesh size) yang berbeda.

Dari gambar 4 terlihat bahwa perlakuan ukuran mata jaring (mesh size) 2 inchi merupakan ukuran tinggi ikan yang tertinggi di semua stasiun (stasiun I, II dan III) dan perlakuan perlakuan dengan ukuran mata jaring (mesh size) 1 inchi merupakan ukuran mata jaring (mesh size) terkecil sehingga cenderung menangkap ikan yang kecil juga.

Untuk melihat adanya pengaruh ukuran mata jaring (mesh size) terhadap ukuran tinggi ikan yang tertangkap dilakukan analisis ragam (anova) yang menunjukan bahwa $\mathrm{F}$ tabel $>$ Ftabel maka $\mathrm{H} 0$ ditolak dan terima $\mathrm{H} 1$ yang artinya perlakuan ukuran mata jaring (mesh size) yang berbeda berpengaruh nyata terhadap ukuran tinggi $(\mathrm{cm})$ ikan yang tertangkap hal ini disebabkan karena ukuran mata jaring insang (mesh size) yang besar hanya menangkap ikan dengan ukuran yang sesuai dengan tinggi ikan, ikan dengan ukuran yang tinggi hanya akan ditangkap oleh ukuran mata jaring (mesh size) yang tinggi juga. Menurut Ayodhyoa (1981) antara mesh size dari gillnet dan besar ikan yang terjerat terdapat hubungan yang erat sekali. Terdapat kecenderungan bahwa suatu ukuran mata jaring (mesh size) mempunyai sifat untuk menjerat hanya pada ikan yang besarnya tertentu. Sehingga gillnet akan bersifat selektif terhadap besar ukuran dari hasil tangkapan yang diperoleh. Oleh karena itu untuk mendapatkan hasil tangkapan dengan jumlah yang besar pada suatu fishing ground, maka ukuran mata jaring (mesh size) harus disesuaikan besarnya dengan besar badan ikan yang menjadi tujuan penangkapan.

Mahiswara et al., (2004) dalam Efton (2015) menyatakan bahwa bentuk tubuh ikan sangat mempengaruhi kemampuan ikan untuk melewati kisi, ikan yang mempunyai bentuk pipih memiliki kemampuan melewati kisi lebih besar dibandingkan dengan yang memiliki bentuk lain. Lebih lanjut Marais (1985) dalam Pratiwi (2010) menyatakan bahwa pada ukuran mata jaring tertentu, ikan yang berukuran sangat kecil bisa menerobos jaring dan ikan yang berukuran sangat besar tidak dapat menembus cukup dalam untuk bisa lolos. Sehingga ikan terkecil yang tertangkap memiliki keliling maksimum tertentu, dan ikan yang paling besar tertangkap memiliki keliling kepala sama dengan mesh perimeter sehingga menyebabkan ikan tersebut terjerat dan kemudian terpuntal.

Dari berbagai uraian diatas maka ukuran (total berat, panjang dan tinggi) ikan yang tertangkap jaring insang pengaruh mesh size yang berbeda di Sungai Lirik dapat dijelaskan bahwa dengan ukuran mata jaring insang (mesh size) yang besar akan menangkap hasil tangkapan ikan yang besar pula begitu juga sebaliknya, ikan yang kecil hanya akan tertangkap oleh mata jaring insang (mesh size) yang kecil juga. Hal ini selaras yang dinyatakan Martasuganda, (2008) yaitu ukuran mata jaring (mesh size) sebaiknya disesuaikan dengan ukuran ikan yang akan dijadikan target tangkapan, atau keliling mata jaring yang akan dipakai harus lebih besar dari keliling bagian akhir penutup insang (operculum) dan harus lebih kecil dari keliling badan maksimal (maximum body) dari ikan yang dijadikan target tangkapan. Konda (1996) dalam Abidin (2000) menyatakan bahwa kisara ukuran yang tertangkap oleh suatu ukuran mata jaring tertentu dapat diprediksi berdasarkan pada hubungan antara panjang dan keliling badan ikan.

\section{B. Pengaruh Ukuran Mata Jaring Insang (mesh size) Terhadap Hasil Tangkapan di Sungai Lirik Kecamatan Jangkat Timur}


Berdasarkan hasil penelitian terhadap total hasil tangkapan ikan yang tertangkap di sungai lirik pada masing-masing stasiun dari setiap ukuran mata jaring (mesh size) dapat dilihat pada lampiran 8. Perbandingan total hasil tangkapan ikan pada setiap stasiun pengaruh perbedaan ukuran mesh size Jaring insang (gill net) dapat dilihat pada Tabel 5 Tabel 5. Total Hasil Tangkapan (ekor) Jaring Insang (Gill Net) Dengan Ukuran Mata Jaring (Mesh Size) Berbeda Di Sungai Lirik

\begin{tabular}{|c|c|c|c|c|}
\hline \multirow[t]{2}{*}{ Stasiun } & \multicolumn{3}{|c|}{ Perlakuan } & \multirow{2}{*}{$\begin{array}{r}\text { Total } \\
\text { (ekor) }\end{array}$} \\
\hline & $\begin{array}{l}1 \text { Inchi } \\
\text { (ekor) }\end{array}$ & $\begin{array}{c}1,5 \text { Inchi } \\
\text { (ekor) }\end{array}$ & $\begin{array}{l}2 \text { Inchi } \\
\text { (ekor) }\end{array}$ & \\
\hline $\bar{I}$ & 18 & 19 & 11 & \\
\hline II & 18 & 16 & 9 & \\
\hline III & 23 & 12 & 10 & \\
\hline Total & 59 & 47,00 & 30 & 136 \\
\hline Rata-rata & 19,67 & 15,67 & 10,00 & 45,33 \\
\hline
\end{tabular}

Sumber : Hasil Penelitian, 07 November $2017-06$ Maret 2018

Dari Tabel 5 dapat dilihat bahwa pada ukuran mata jaring (mesh size) 1 inchi jenis ikan yang tertangkap 59 ekor, yang terdiri dari ikan semah (Labeobarbus tambra) sebanyak 52 ekor dan ikan Cato dengan nama nasional Ikan Kepyur (Barbodes lateristriga) sebanyak 7 ekor. Selanjutnya perlakuan dengan ukuran mata jaring (mesh size) 1,5 inchi didapatkan sebanyak 47 ekor yang terdiri dari 46 ekor ikan Semah (Labeobarbus tambra) dan 1 ekor ikan Baung Sungai (Hemibagrus nemurus ), sedangkan pada perlakuan dengan ukuran mata jaring (mesh size) 2 inchi adalah total hasil tangkapan yang paling sedikit yaitu sebanyak 30 ekor dan semuanya adalah ikan Semah (Labeobarbus tambra). Sehingga dapat dikatakan bahwa semakin besar ukuran mesh size jaring insang semakin sedikit ikan yang tertangkap sedangkan ukuran mesh size jaring insang yang kecil menghasilkan tangkapan yang lebih banyak. Menurut Ayodhyoa (1981), untuk mendapatkan hasil tangkapan yang besar jumlahnya, maka ukuran mata jaring harus disesuaikan dengan besar ikan yang jumlahnya terbanyak pada suatu fishing ground. Dengan ukuran mesh size yang tepat ikan-ikan kecil diberi kesempatan untuk tumbuh dan berkembang sehingga tidak akan mengurangi stok di kemudian hari. Dengan memperbesar mesh size jumlah ikan tertangkap cenderung akan menurun namun berat dan ukuran ratarata ikan akan meningkat. Kaban, dkk (2015), menyatakan bahwa ikan yang tertangkap di Sungai Batang Hari adalah sebanyak 37 pada inchi dan 36 ekor pada 1,5 inchi sedangkan untuk ukuran jaring 3 inchi hanya menangkap ikan yang berukuran relatif besar atau induk ikan dengan jumlah yang sedikit yaitu 5 jenis ikan dengan jumlah 7 ekor. Untuk melihat histogram total hasil tangkapan disajikan pada Gambar 4. di bawah ini.

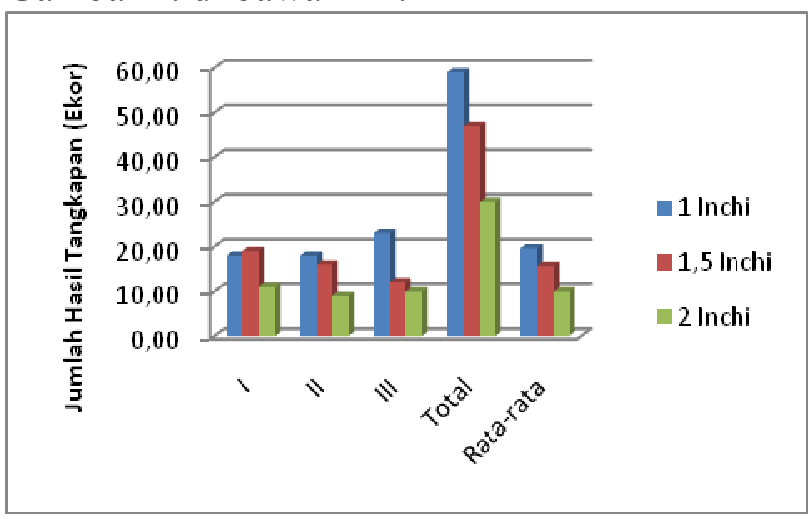

Gambar 4. Histogram total hasil tangkapan (ekor) jaring insang pengaruh ukuran mesh size yang berbeda

Berdasarkan gambar 4. di atas dapat dijelaskan bahwa hasil tangkapan ikan jaring insang ukuran mesh size 1 inchi merupakan perlakuan dengan hasil tangkapan paling banyak pada setiap stasiun (Stasiun I, II dan III) dan di ikuti oleh perlakuan dengan ukuran mesh size 1,5 inchi. Sedangkan hasil tangkapan ikan yang sedikit terdapat pada perlakuan ukuran mesh size 2 inchi, hal ini juga tergambar pada jumlah hasil total tangkapan dan rata-rata hasil tangkapan dengan alat tangkap jaring insang di Sungai Lirik Kecamatan Jangkat Timur Kabupaten Merangin. Menurut Sparred an Venema (1999) dalam Efton (2015), Ukuran ikan yang kecil menyebabkan jaring dengan ukuran mata lebih kecil akan mendapatkan hasil lebih banyak karena jaring tersebut ikan berbagai ukuran secara terjerat pada bagian insang (gilled), terjerat pada seluruh tubuh ikan (wedged), maupun terjerat pada sebelum tutup insangnya (snagged).

Untuk mengetahui berpengaruh atau tidaknya ukuran mata jaring insang (mesh size) 
yang berbeda terhadap total hasil tangkapan ikan di Sungai Lirik maka dilakukan analisis ragam (anova), Hasil analis ragam menunjukan bahwa $\mathrm{F}_{\text {hitung }}>\mathrm{F}_{\text {tabel }}$ maka Ho ditolak dan $\mathrm{H} 1$ diterima yang berarti perlakuan Perbedaan ukuran mata jaring (mesh size) alat tangkap Jaring insang berpengaruh nyata terhadap jumlah total (ekor) ikan yang tertangkap hal ini disebabkan karena mesh size jaring insang yang besar akan menghasilkan jumlah tangkapan yang sedikit bila dilihat dari sisi ukuran total (berat, panjang dan tinggi) dan ukuran mata jaring yang kecil akan mengasilkan jumlah tangkapan yang banyak bila dilihat dari dari sisi jumlah total (ekor). Abidin (2000) dan Pratama (2012) juga menyatakan bahwa ukuran mata jaring yang berbeda pada jaring rampus berpengaruh nyata terhadap jumlah total ikan yang tertangkap. Pada ukuran mata jaring tertentu, ikan yang berukuran sangat kecil bisa menerobos jaring dan ikan yang berukuran sangat besar tidak dapat menembus cukup dalam untuk bisa lolos. Sehingga ikan terkecil yang tertangkap memiliki keliling maksimum tertentu, dan ikan yang paling besar tertangkap memiliki keliling kepala sama dengan mesh perimeter sehingga menyebabkan ikan tersebut terjerat dan kemudian terpuntal (Marais, 1985 dalam Pratiwi, 2010).

\section{Jenis-Jenis Ikan Yang Tertangkap dengan Alat Tangkap Jaring insang Ukuran Mata Jaring (mesh size) Yang Berbeda}

Adapun hasil penelitian terhadap jenis ikan yang tertangkap oleh alat tangkap jaring insang di sungai lirik pada setiap ukuran mesh size dapat dilihat pada lampiran 10 (halaman 59). Berdasarkan hasil penelitian dapat dijelaskan bahwa jumlah total ikan yang tertangkap selama penelitian adalah sebanyak 136 ekor yang terdiri dari 3 jenis ikan yaitu 128 ekor ikan Semah (Labeobarbus tambra), 7 ekor ikan Kepyur (Barbodes lateristriga) dan 1 ekor ikan Baung (Hemibagrus nemurus). Perbedaan mata jaring insang (mesh size) juga menyebabkan jenis ikan yang tertangkap hal ini dapat dilihat pada mesh size 1 inchi jenis ikan tertangkap adalah 52 ekor ikan Semah (Labeobarbus tambra) dan 7 ekor ikan Kepyur (Barbodes lateristriga), pada ukuran mesh size 1,5 inchi tertangkap 46 ekor semah (Labeobarbus tambra) dan 1 ekor ikan Baung (Hemibagrus nemurus) sedangkan pada ukuran mesh size 2 Inchi hanya tertangkap 30 ekor ikan semah (Labeobarbus tambra).

Meskipun terdapat perbedaan jenis ikan yang tertangkap pada setiap ukuran mesh size tetapi secara umum hasil tangkapan jaring insang di Sungai Lirik dengan mesh size yang berbeda didominasi oleh ikan Semah (Labeobarbus tambra) yaitu 94,12 \% dan diikuti Ikan Kepyur (Barbodes lateristriga) $5,15 \%$ dan ikan baung (Hemibagrus nemurus) $0,74 \%$. Dominanya ikan Semah (Labeobarbus tambra) $(94,12 \%)$ di semua ukuran mata jaring (mesh size) di Sungai Lirik ini dapat dikatakan bahwa Sungai Lirik merupakan habitatnya ikan Semah (Labeobarbus tambra). Habitat adalah tempat suatu makhluk tinggal dan berkembang biak. Pada dasarnya habitat merupakan lingkungan fisik yang ditempati populasi suatu spesies kemudian dimanfaatkan oleh spesies tersebut. Dengan demikian habibat dapat mempengaruhi kelangsungan hidup spesies tersebut. Habitat asli ikan semah umumnya di danau dan sungai dengan air yang berarus deras.

Menurut Haryono dan Subagja (2008), habitat ikan semah di perairan terdapat di lubuk sungai yang berarus deras kedalaman air ratarata diatas 2 meter, dasar perairan bebatuan, substrat tersusun dari pasir dan kerikil. Lebih lanjut Utomo dan Krismono (2006), menyatakan bahwa habitat yang di tempati ikan semah adalah habitat yang memiliki suhu perairan rendah, oksigen terlarut yang tinggi, arus sungai yang deras dan beriak. Di dasar sungai tersusun atas pasir dan bebatuan.

Menurut Haryono dan Subagja (2008:307) struktur populasi ikan semah terdiri dari : anakan, remaja, dan dewasa. Anakan ikan semah panjang tubuhnya di bawah $30 \mathrm{~cm}$, ukuran remaja dengan kisaran panjang 31-40 $\mathrm{cm}$ dan dewasa dengan panjang lebih dari $51 \mathrm{~cm}$. Berdasarkan seluruh hasil tangkapan ikan semah yang didapat di lokasi penelitian didominasi ikan semah anakan. 


\section{KESIMPULAN DAN SARAN}

\section{Kesimpulan}

Berdasarkan hasil penelitian ini dapat ditarik kesimpulan sebagai berikut :

1. Perbedaan mata jaring (mesh size) alat tangkap Jaring insang (gillnet) 1 inchi, 1,5 inchi dan 2 inchi berpengaruh nyata pada taraf $95 \%$ (F Hit > F Tabel) terhadap ukuran ikan (berat $(\mathrm{Kg})$, panjang $(\mathrm{cm})$ dan tinggi $(\mathrm{cm})$ ikan), jumlah total (ekor) ikan yang tertangkap di sungai Lirik Kecamatan Jangkat Timur Kabupaten Merangin propinsi Jambi.

2. Jenis ikan yang tertangkap dengan ukuran mata jaring (mesh size) yang berbeda yaitu ukuran mata jaring (mesh size) 1 inchi jenis ikan yang tertangkap ikan Semah (Labeobarbus tambra) sebanyak 52 ekor dan ikan Kepyur (Barbodes lateristriga) sebanyak 7 ekor, ukuran mata jaring (mesh size) 1,5 inchi tertangkap 46 ekor Semah dan 1 ekor ikan Baung sedangkan ukuran mata jaring (mesh size) 2 Inchi hanya tertangkap 30 ekor ikan Semah sehingga ikan yang tertangkap di sungai Lirik di jumpai 3 jenis ikan yaitu semah sebanyak 128 ekor, ikan Kepyur 7 ekor dan ikan Baung sebanyak 1 ekor

3. Ukuran mata jaring insang (mesh size) yang tebaik digunakan adalah :

1. Berdasarkan ukuran ikan, jaring insang (Gillnet) yang terbaik digunakan adalah ukuran mata jaring (mesh size) 2 Inchi.

2. Berdasarkan hasil tangkapan, jaring insang (Gillnet) yang terbaik digunakan adalah ukuran mata jaring (mesh size) 1 Inchi

\section{Saran}

Berdasarkan hasil penelitian maka disarankan untuk menggunakan alat tangkap jaring insang (gill net) dengan ukuran mata jaring (mesh size) 2 inchi karena lebih ramah lingkungan, dan disarankan melakukan penellitian lebih lanjut di Sungai Lirik tentang ekologi perairan maupun alat tangkap yang lain.

\section{DAFTAR PUSTAKA}

Abidin Z. 2000. Studi tentang selektivitas jaring rampus terhadap ikan kembung (Rastrelliger spp) di Teluk Jakarta [Skripsi]. Bogor: Institut Pertanian Bogor.

Ayodhyoa AU. 1981. Metode Penangkapan Ikan. Bogor : Yayasan Dewi Sri. Bogor.

Bahar. M. Dan A.C Dincer. 2008. Dincer AC, Bahar M. 2008. Multifilament gillnet selectivity for the Red Mullet (Mullus barbatus) in the Eastern Black Sea Coast of Turkey, Trabzon. Turkish Journal of Fisheries and Aquatic Sciences. 8:355359.

Delly, D.P.M. 2011. Efisiensi Penangkapan Jaring Insang Lingkar Dengan Ukuran Mata Jaring Dan Nilai Pengerutan Yang Berbeda Di Perairan Pesisir Negeri Waai. Jurnal Pengembangan Pulau-Pulau Kecil 2011 - ISBN: 978-602-98439-2-7. Di Unduh 28 Maret 2018

Febriansyah. 2011. Komunitas Makrozobentos Di Sungai Batang Hari Kabupaten Solok Sumatera Barat. [Skripsi]. Jurusan Biologi. Fakultas Matematika Dan Ilmu Pengetahuan Alam. Universitas Andalas. Padang

Firmansyah. 1988. Suatu Studi Perbandingan Hasil Tangkapan Jaring Rampus Dengan Ukuran Mata Jaring Yang Berbeda Di Teluk Lampung, Propinsi Lampung. Karya Ilmiah. Pemanfaatan Sumber Daya Perikanan IPB. Bogor.

Haryono dan J Subagja. 2008. Populasi dan habitat ikan Tambra (Tor tambroides. Bleeker, 1854) di perairan kawasan pegunungan Muller Kalimantan Tengah. Biodiversitas (9):4: 306-309.

Heikinheimo O, Setälä J, Saarni K, Raitaniemi J. 2006. Impacts of MeshSize Regulation of Gillnet on the Pikeperch Fisheries in the Archipelago 
Agustus 2018

Sea, Finland. Fisheries Research. 77(2):192-199.

Iskandar. D, Rosyidin dan P. A. Singgih. 2015. Variasi Jumlah Dan Jenis Hasil Tangkapan Jaring Rampus Pada Ukuran Mata Jaring Yang Berbeda Di Perairan Teluk Jakarta. Maspari Journal Januari 2016, 8(1):49-58

Jangkat Timur Dalam Angka. 2015.

Kaban. S, Asyari, K. Fatah, M. Marini, T. Nanda, Burnawi, D. H. Nasution dan Mersi. 2015. Kajian Tingkat Degradasi Dan Potensi Sumber Daya Ikan Di Sungai Batanghari, Jambi (Laporan Teknis Tahun Anggaran 2015). Balai Penelitian Perikanan Perairan Umum Palembang. Kementerian Kelautan Dan Perikanan. Palembang

King M. 1995. Fisheries Biology, Ascesment and Management. Faculty of Fisheries and Marine Environtment. Australian Maritime College.

Ledhyane. I.H, 2013. Analisis Ragam \& Rancangan Acak Lengkap.Statistik (MAM

4137).ledhyane.lecture.ub.ac.id/files/201 3/07/RAL-2013.pdf. Diunduh 20 Maret 2017.

Manalu, M. 2003. Kajian Output yang Dihasilkan Operasi Penangkapan Jaring Kejer di Teluk Banten.: Departemen Pemanfaatan Sumberdaya Perikanan, Fakultas Perikanan Dan Ilmu Kelautan, Institut Pertanian Bogor. 